\title{
POSTCLASSIC FINDS IN THE CAYO DISTRICT, BELIZE*
}

\section{Por: Peter J. Schмidt}

The present-day country of Belize falls within the cultural area of the Southern Maya Lowlands. On all soils suitable for agriculture, it bears evidence of a dense Maya population over a long period of time.

Especially heavy settlement concentrations occur in its Western or Gayo District bordering with the Departament of El Petén in Guatemala. In the fertile bottomlands of the wide Belize River Valley habitation mounds and plazuela groups cluster in groups of varying size, and form a nearly continuous zone of settlement. Further upstream, along and between the Macal and Mopan, the two branches which form the Belize River, this concentration continues, including much of the adjoining hill country. A typical section of the northern part of this continuum is the Barton Ramie site, investigated for Harvard University by Gordon Willey and others (Willey et al., 1965).

Ceremonial groups and minor to medium size centres are interspersed, with an apparent increase in density as one moves up-river. Between the Macal and Mopan they are generally not more than three miles distant from each other. Stone monuments were erected at many of them and major architectural construction is a common feature. Most impressive among these ceremonial and probably administrative centres is Xunantunich, formerly often called Benque Viejo, on a hilltop approximately one mile due west of the Mopan and the village of San José Socotz, some ten miles above the junction of this river with the Macal. Work on this site (which in turn seems to be closely connected in styles and layout to the major centres of Caracol, further south, and Naranjo, further west), has

* Paper Presented at the XXXIXth Int. Congr. of Americanists Lima, 1970 
been done by several investigators. Most of this work was disorganized and haphazard, notable exceptions being the stratigraphic excavations of J.E.S. Thompson in 1938 (Thompson, 1940), and excavations by a Cambridge students' expedition in 1959 (MacKie, 1960). Thompson investigated a small group close to the site centre and established the pottery sequence "Benque Viejo I" to "Benque Viejo IV".

His last "phase", Benque Viejo IV, corresponds to Tepeu 3 at Uaxactún, San José IV-V, and the latest facet of the Spanish Lookout Phase at Barton Ramie. In recent years it has become evident that these phases already belong to a period when organized largescale activities at the ceremonial centres had terminated, which means they cannot be included any more into the "Classic" Period as such. Smith and Gifford called them "Transition" or "Proto-Postclassic" (Smith and Gifford, 1965, pp. 105-06). Evidence at Xunantunich, as presented by MacKie, fully supports this assigment, further borne out buy recent finds at the main structure of the site: a room there shows squatter-type occupation by people using Benque Viejo IV pottery. Also at Cahal Pech, a centre near the town of El Cayo, Tepeu-3-related finds appear to be post-constructional. The temporal extent of this Transition or Proto-Postclassic Period was probably not too long. Reported surface finds from all mentioned sites are mostly Late Classic and/or Proto-Postclassic.

The same northern Cayo region discussed so far was a relatively important population centre in Early Colonial times, at least up to the late seventeenth century. The famous villages or towns of Lucu and Tipu must be located in this region (Bullard, 1965, pp. 10-11; López de Cogolludo, ed. 1867-68, Vol. 2, Bk. 9; Willey et al., 1965, pp. 27-28; Roys, 1957, pp. 163-64). Tipu, the most important station for most early expeditions sent out to deal with, to convert and finally to conquer the free Itza of Tayasal, was a place where numerous Maya from Yucatán used to seek refuge from Colonial state and church, although it was nominally controlled by the authorities in Bacalar. Its identity with some site in the vecinity of modern El Cayo is more than probable, especially if one compares the last part of the missionaries' voyage, as described by Cogolludo, with Teobert Maler's account and plan of the route between Cayo and Flores, the modern successor of Tayasal, as used in the early days of our century (Maler, 1908, pp. 125-27 and fig. 9). They correspond closely to each other, and one end of the routs being fixed, the other can be reasonably assumed to be the same as well. Apparen- 
tly here, as in many other parts of the world, an ancient trade and travel route had been retained and formed the basis for communications up to recent times, when improved road-building equipment and techniques made the choice of a more direct alignment possible.

To identify Tipu or other Colonial sites, which are probably without major architectural remains (-although Tipu itself is reported to have had a church-) among thcusands of unexcavated mounds of the area should require a very accurate site survey with numerous test-excavations, a type of program which has not been applied to this particular problem so far. Reported surface finds are, as mentioned, mostly Late Classic and Proto-Postclassic, but this could be easily motivated by the more spectacular character of Late Classic material in general, which is much more willingly collected than a coarse Postclassic or Colonial sherd. Furthermore, there might have been a shift from ceramics to containers fashioned out of other material, like gourds and wood, as suggested by Thompson. In any case, the historical sources are explicit enough to establish a fairly dense settlement of the area in early Colonial times.

If now, the Late Classic and Proto-Postclassic are represented by abundant archaeological material and the Colonial Period settlement is well attested by written sources, the most important question to answer is what exactly happened during Postclassic times in the area. Was there a break in occupation?. The fact that the Yucatecan element in the Colonial population was said to be predominant, could point into this direction. Or was the occupation continuous?. If so, the next question is, if Yucatecan influence was already strong before the Spanish Conquest or if it became so only after refugees from the Spanish flocked into the area from farther north. The probability has been mentioned above, that the Cayo area, very rich in agricultural resources, among which cacao is especially mentioned, was situated right on an ancient route from Northern Yucatan to the Central Petén. In Postclassic times the most vigorous developments in Maya culture took place in the North. On the other hand, the political situation there was such, due to constant warfare, invasions, and dynastic troubles, that periodically many people had to seek refuge in the bush. Pushing south along the well known trade route and securing a hold on the rich economic resources of the Belize River Valley would be only logical for such dislocated groups. In fact the refugees of Conquest times might have followed an ageold pattern, well established in their time already.

For the first part of the (conventional) Postclassic Period, Willey 
and his colleges demonstrated another phase of dense settlement at Barton Ramie. This is the New Town Phase, characterized by some very distinctive pottery modes, but apparently lacking most of the elaborations of higher culture which had been typical of the Classic. It is considered Early Postclassic and the time span given to it is approximately $950 \mathrm{~A}$. D. to $1100 \mathrm{~A}$. D., with the ending date being uncertain, however (Willey et al., 1965, pp. 27-28, 568-69).

Willey defined the New Town Phase as "a phase which appears to be representative of a continuing peasant population in the outlying communities after the cessation of activities in the ceremonial centres" (p. 578). This of course revalidates Thompson's old suggestion that the downfall of Classic culture was not accompanied by a complete population displacement but consisted in a possibly violent change of social conditions (Thompson, 1931, pp. 230-31). The same description, however, fits already the immediately preceding Transition or Proto-Postclassic Period mentioned above, possibly with the difference that even secondary, squatter-type use of the abandoned centres decreased with time. Thompson originally attributed the final large-scale depopulation of the Southern Lowlands to the introduction of European diseases in the sixteenth and seventeenth centuries.

Dating of the New Town Phase as basically Early Postclassic leaves a major hiatus between approximately the twelfth century (end of Early Postclassic) and Colonial times again. Seeing the difficulties thenselves, Willey et al, wrote: "... or it may be that some kind of a village was maintained here as a prolonged aftermath of our New Town manifestation, either continuously or intermittently, down to the seventeenth century..." (Willey et al., 1965, p. 571).

During the last two years, the Department of Archaeology of Belize has been working with a certain emphasis on the Cayo District, especially concerned, of course, with salvage and consolidation of Xunantunich. The search of evidence for Postclassic and Colonial Period remains, however, was always kept in mind, and although unsuccessful on the Colonial side so far, met with some small success in the Postclassic field.

Typical scroll - and bell - shaped feet of New Town Phase types were found in superficial deposits in the main plaza at Xunantunich, close to two carved stelae. One of them, although badly eroded and broken, seems to have remained above ground since its erection in Late Classic times and might have been the focus for some of these Postclassic activities. 
POSTCLASSIC FINDS IN THE GAYO DISTRICT, BELIZE 107

A single vessel of the Bowman collection, now part of the National collection in Belize and said to have come from the Benque Viejo regions, shows an effigy-type fairly common in Mayapán: a human face looking out of the open jaws of a turtle or crocodile effigy vessel. This correlates quite well with Gann's finds from Northern Belize and the Mayapán ceramics in the Mérida Museum.

The third and most important group of finds came from a cave discovered in 1968 and further excavated in 1970. The cave called Uchentzub (Agouti Cave) by its discoverer, is situated in the limestone hills approximately $5 \mathrm{~km}$. East-South-East of Socotz, close to the Western bank of the Macal River. On a hillside, from a sinkhole approximately $50 \mathrm{~m}$. in diameter and $5 \mathrm{~m}$. deep and completely overgrown by tropical forest, numerous caves of varying size branch off into every direction. Some of them are fairly large and show in parts extensive surface deposits of Late Classic and Proto-Postclassic pottery, others are only compartively small hollows in the limestome rock.

Cave No. 1 'Fig. 1), a small and very low chamber of approximately $7 \mathrm{~m}$. East-West and $8 \mathrm{~m}$. North-South extension, contained besides sporadic finds of Late Classic date, mostly potsherds, an important Postclassic assemblage. Close to the back wall of the chamber, in the only part where it is possible to stand upright, and by the side of a huge stalagmite formation attached to the wall, were found:

Four incense-burners (27/188-1: 2, 4, 5 and 7), one incense-burner base (27/188-1: 3), one plain pottery vessel $(27 / 188-1: 6)$, three conical lumps of copal $(27 / 188-1: 8,9$, and 10), and one staff-like wooden object $(27 / 188-1: 25)$.

The pottery vessels were lying on their sides or upside down. Most of the finds were half interred in the soft brownish soil mixed with bat-guano which covers the rear half of the cave. Disturbance, at least during the last fifty or hundred years, seems to be out of question. Two short, irregular rows of stones on the surface roughly deliminate the main area of deposition.

Near the centre of the chamber, another group of objects was located on the surface, the dust-like soil being here only some $3 \mathrm{~cm}$. deep:

One fragmentary wooden disk or plate $(27 / 188-1: 24)$, one irregular wooden object with traces of burning (27/188-1: $26)$, and one pottery disk (27/188-1: 18). 
Finally, close to the narrow and low entrance, set on top of a flowstone deposit, were found:

One pottery effigy hand with a short tenon (27/188-1: 1), one rectangular jade bead (27/188-1: 17), and

one large conical lump of copal, probably mixed with rubber (27/188-1: 11).

With the possible exception of the pottery disk, which was dug out of the soil accidentally, all three groups of objects seem to belong together and to date from approximately the same time. The condition of the wood in the central group is identical with that of the wood in the main group and the copal cone as well as style and material of the pottery effigy hand correlate the group near the entrance with the main group.

\section{Description of the finds:}

The pottery hand (27/188-1: 1 ; fig. 8 a.) $, 7,5 \mathrm{~cm}$. long and fashioned in an open position with slightly bent fingers and with a bracelet of eleven appliqué pellets around the wrist, has a short tenon where it should be joined to the arm. It seems to be complete in itself, but, of course, the possibility cannot be ruled out that once it formed part of a larger composite assembly which was taken out of the chamber again, either by its original users or by some pothunter who entered the cave but did not penetrate enough to reach the incense burners and the pottery vessel. This last possibilty is rather improbable, however, for he would have certainly taken the jade bead.

Three of the incense burners are pedestal-base vase censers (27/ 188-1: 2, 5, and 7) between 16 and $20 \mathrm{~cm}$. high. In form they are slightly different from each other, but composed of the same basic elements: a high pedestal base, a comparatively low body, and a high sloping neck with direct or exterior-thickened rim. They are unpolished, unpainted, and decorated only in appliqué. Disks and spikes in various combinations are attached to the body at its widest diameter, and clay ribbons with evenly spaced impressions cover the junctions between pedestal base and body, in two cases also between body and neck. Colours vary between brown, grey, and red, with large firing clouds. In many places the surface is worn away, exposing clearly the calcite temper of the vessels. The interior is heavily blackened.

The one fragmentary incense burners (27/188-1: 3; Fig. 36), 
consists of the pedestal base and bottom of an identical vessel, cleanly broken immediately above the ribbon at their junction.

The last of the incense burners (27/188-1: 4; fig. 4a.), $15 \mathrm{~cm}$ high, is also set on a high pedestal. The body, however, consists of $a$ shallow bowl with a direct horizontal rim. Four holes, $1 \mathrm{~cm}$. below the rim, evenly spaced around the diameter, probably served either for fastening a lid onto it or for hanging it up or swinging it on strings. It is fired red all over, with some firing clouds, only the outside and the rim of the bowl being slipped and polished. Just above the junction between bowl and pedestal, a fringe or flange of hanging fourstepped elements, which look like inverted pyramids, is attached. Originally, there were six of those elements, but now only five are left. Apparently the censer was already deposited in this defective condition, for the missing element could not be found in the excavation.

The single pottery vessel (27/188-1: 6 ; fig. $4 \mathrm{~b}), 14,5 \mathrm{~cm}$. high, is a flattened globular olla, with a straight, short neck and direct rim. The surface is unpolished, unpainted, and of a dark-grey to reddish colour with large firing clouds. The bottom of the vessel, which was found upside down, is partly broken out.

Of the three copal cones found with the main group, the two smaller ones (27/188-1: 8 and 9; figs. $5 \mathrm{~b}$ and $5 \mathrm{c}), 7,0 \mathrm{~cm}$. and 8,5 $\mathrm{cm}$. high, are fairly irregular, apparmently built up out of equally irregular lumps of copal. In the centre of the top they have one hole each, probably once holding a wick, either a little stick or a piece of string or cotton. The surface appears spongy and is of a very light brown colour.

The biggest cone of the three (27/188-1: 10; fig. 5A) is fairly regularly shaped, $10.3 \mathrm{~cm}$. high and $8 \mathrm{~cm}$. wide at the bottom. It is built up on an apparently well prepared platform of copal and has the same hole at the top as the other two. On the outside, traces of blue painting with a greenish tinge are still visible, at the bottom a clear imprint of what appears to be a cornhusk can be recognized.

The cone found apart from the others $(27 / 188-1$ : 11 ; fig. 6) show some peculiarities. It is $17,8 \mathrm{~cm}$. high and presently has disintegrated into two parts, an outer layer of copal of the usual spongy, light brown appearance, and an inner core of dark grey to black material which gives a definite smell of rubber when burned. A stick forms the centre of the rubber (?) core, again possibly intended to serve as a wick. In the copal, several layers are recognizable, each one painted the same blue-greenish tinge mentioned before. The 
disintegration is probably due to the diferential shrinkage and/or absorption rates of rubber and copal.

The fragment of a wooden disk or plate (27/188-1: 24; fig. $7 \mathrm{~b})$ still consists of nearly one-third of an originally circular or oval flat object, approximately $1,2 \mathrm{~cm}$. thick and of $22-24 \mathrm{~cm}$. diameter. One side at least seems to have been smoothed. The type of wood has not yet been identified.

The staff-like wooden object (27/188-1: 25; not illustrated) found in front of the main group is without any preserved surface features. It is $24 \mathrm{~cm}$. long, $4,4 \mathrm{~cm}$. wide and $3 \mathrm{~cm}$. thick. Its artifact-character is doubtful.

The irregular wooden object (27/188-1: 26; fig. 7a.) found with the centre group, $19 \mathrm{~cm}$. long, shows in two or three places traces of burning. It is too destroyed to determine if it might have been used for a torch, to hold burning copal, or for some other purpose.

The rectangular jade bead (27/188-1: 17 ; fig. $8 b)$ is of mottled light green jade, with a small, even hole bored through the long axis, apparently by drilling from both sides. It is $2,5 \mathrm{~cm}$. long and 0,7 to $0,9 \mathrm{~cm}$. thick.

The pottery disk (27/188-1: 18; fig. 8c) is cut out of a potsherd, roughly circular, of 5,8 to $6,6 \mathrm{~cm}$. diameter and $0.5 \mathrm{~cm}$. thick. Its association with the rest of the material is doubtful.

The assemblage as a whole probably represents equipment for offerings or other ceremonies held within the cave. A burial association is improbable, since excavations so far have not discovered a single bone. and location above the cave floor precludes interpretations as a cache of hidden goods as well. Thompson presents some information on the use of caves by the Maya in times of the Spanish Conquest, for rites to win rain, good crops, and good hunting. Numerous incense-burners were associated with these rites (Thompson, 1959, p. 123).

The date of the Uchentzub finds is definitely Postclassic. The closest parallels to the Uchentzub pottery occur in the late, intrusive Caban Complex of Tikal, where practically identical censers were found in a burial pit in the backroom of Temple 1 (Burial 5; Adams and Trik, 1961, esp. fig. 42). They were supposedly associated with examples of Ixpop Polychrome and Paxcamán Red pottery, both of which are also typical for the New Town Phase of the Belize River Valley. If this association is valid, it would put our finds from Uchentzub into the New Town Phase as well, defined as Early Postclassic by Willey and others, as explained above. Another interest- 
ing circumstance of the Temple 1 find in Tikál is that many lumps of copal were found together with the pottery, as well as four balls of copal, perfect with a hole for the wick, blue painting and corn husk impressions at the bottom, which formed the content of an unsealed cache under a step close to the burial pit (Cache 37). Both the Tikál and Uchentzub censers probably originated within the same cultural group, centered in the area between Lake Petén and the Belize River Valley. No comparable censer fragments have been found at Barton Ramie, but that might be explained by the different context of housemounds as compared to a probable cave shrine.

Another close parallel, however, bridges a much wider distance: the pedestal-base censers of Uchentzub (and Tikál) are practically duplicated at Mayapán in northern Yucatán, where the corresponding finds are assigned to the Middle and Late Postclassic Hocabá and Tases-Complexes. Closest parallels exist in the Hoal Ceramic Group of the Hocabá and possibly in the Chen Mul Group of the Tases Complex (Smith and Gifford, 1965, pp. 529-31, esp. fig. 14). Censers examined in the Mérida Museum are nearly identical to our finds. The straightnecked olla would fit into the same group. The red pedestal-base burner from Uchentzub is best compared with Mayapán Red Ware examples, where the same modes occur, including that of a fringe of hanging stepped elements. The pottery hand fits in style easily within the large series of effigy censers, dated as Late-Postclassic in Yucatán. (Smith and Gifford, 1965, figs. 15 and 16). Large quantities of blue-painted copal were found in the Sacred Cenote at Chichen Itzá, and in Conquest times, according to Landa's Relación, it was in general use all over Yucatan (Landa, ed. 1941, pp. 75, 110).

Apparently there is a contradiction in the evidence then: all the Uchentzub material could be easily cross-dated with Yucatecan types as Middle to Late Postclassic, is however tied in with Early Postclassic at Tikal. The associated materials in Tikál are items of a New-Town-Phase-related complex, whereas in the New Town Phase itself no corresponding material is represented. Furthermore, Ixpop Polychrome and Paxcamán Red imitate X-Fine-Orange types, firmly dated as Early Postclassic elsewhere (Willey et al., 1965, p. 388; Adams and Trik, 1961, pp. 128-29). The Tikál excavators were well aware of the problem.

One solution would obviously be to extend the time range allowed for the Town Phase and related complexes so as to cover the whole of the Postclassic Period, implying a complete continuity in settlement. 
Nevertheless, definite association of Early and Late Postclassic material, paralleled elsewhere in groups separated by centuries, remains highly unlikely. Unfortunately, I am not familiar with Bullard's results from his Topoxté excavations, nor Cowgili's report en the Postclassic of Flores, Petén, which must throw some ligth on this matter.

In the meantime, another solution should be considered: New Town Phase and Burial 5 in Tikál are Early Postclassic, Uchentzub, however, is Late Postclassic, and the censer fragments in Tikal do not belong to the burial.

Burial 5 was extensively disturbed, the last time before the excavation apparently by Bernoulli's men in 1877 (Adams and Trik, 1961, p. 133). The reconstruction of events in the 1961 report was:

1) Introduction of Burial 5 into the shaft on top of a Late Classic Burial (Burial 6), in Postclassic times

2) Deposition of a thick layer of bat dung in the open grave pit, at unknown time

3) Disturbance of Burial pit, at unknown time

4) Refilling of the pit probably by Bernoulli's workmen in 1877 .

If we separate Early and Late Postclassic material, however, the history of the pit becomes more complicated:

1) Introduction of Burial 5 into the shaft on top of Late Classic Burial 6, and first refilling of the pit, in the Early Postclassic

2) Deposition of censers and incense on the surface, possibly during a ritual which used the abandoned room as well-suited for cave-ceremonies, in the Late Postclassic

3) Early disturbance and looting of burials, leaving pit open, which partly filled with bat guano

4) Initial clearing of room and dumping of remaining grave good fragments as well as broken surface material into the pit, probably by Bernoulli's men as preparation ot their scaffolding and lintel-cutting work.

5) Final refilling, including cut-off lintel ends and scaffolding material.

In this reconstruction, not only formal but functional correspondence between the censer finds at Tikal and Uchentzub is assumed.

As well as the first solution, this one indicates a fairly continuos occupation of the region during Postclassic times. By extending the New Town Phase, however, we would have domestic material to go 
along with the censers; by assingning New Town to Early Postclassic, Uchentzub to Late Postclassic, material for these later phases would be restircted, at present, to nothing more than a few incense burners and ceremonial paraphernalia. The settlements of Middle and Late Postclassic, then, wolud be probably in different places from those of the Early Postclassic which had continued to occupy the Classic and even Pre-Classic house mounds.

This implies some major dislocation or depopulation at the end of the Early Postclassic Period. If such a dislocation could be established as a fact, it would offer interesting room for speculation how it was connected with the semihistoric Itza-migrations of the $\mathrm{Yu}$ catecan Chronicles, which according to some versions should háve touched our region around this time. Until this continuity problem of Early to Late Postclassic is settled, one of the most important questions asked at the beginning of this paper has to remain unsolved: how far did the Early Colonial population descend directly from the Late Classic occupants of the area?

The second question was about character and temporal extent of ties with Yucatán. At Ieast as far as can be judged from pottery and its use in rituals, they were definitely strong in the Middle and Late Postclassic already, so that the influx of Yucatecan elements must be regarded as older than Conquest times. If this influx, however, consisted only in the transmission of ideas and goods or if it was an actual colonization, we do not wnow. In case it was an actual migration, we do not know yet if the new settlers found somebody still living in the area and if and how assinmilation and acculturation processes worked.

The finds of Uchentzub provide one more important link, but we are far from recognizing the whole chain of events and developments taking place during Postclassic times in the Southern Lowlands.

August, 1970

\section{BIBLIOGRAPHY}

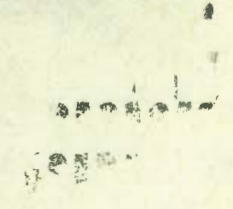

R. E. W. Adams \& A. S. Trick

1961 Temple 1 (Str. 5D-1): Post-Constructional Activities; Tikal Report No. 7; In: Adams, Broman, et al: Tikal Reports Nos. W. R. Bullard 5-10., Philadelphia.

1965 Stratigraphic Excavation at San Estevan, Northern British Honduras; Toronto. 
T. P. Gulbert

1967 Preliminary Report of the Conference on the Prehistoric Ceramics in the Maya Lowlands; In: Estudios de Cultura Maya VI, pp. 81-109; Mexico.

Fr. Diego de Landa

1941 Landa's Relación de las cosas de Yucatán; Papers Peabody Museum XVIII; Cambridge.

Fr. Diego López Cogolludo 1867 - 68 Historia de Yucatán (I, II) 3a. ed.; Mérida.

E. W. MAGKIE

1960 Archaelogical Work at the Ruins of Xunantunich, a Maya Ceremoniali Centre; In: Cambridge Expedition to British Honduras, General Report; Cambridge.

T. MALER

1908 Explorations in the Department of Petén, Guatemala, and Adjacent Region; Memoirs Peabody Museum IIV, 2; Cambridge.

R. L. Roys

1957 The Political Geography of the Yucatan Maya; Washington.

R. E. Smith \& J. C. Gifford

1965 Pottery of the Maya Lowlands; In: Handbook of Middle American Inidans, Vol. 2, pp. 498-534; Austin.

J. E. S. Thомpson

1931 Archaeological Investigations in the Southern Cayo District, British Honduras; Chicago.

1939 Excavations at San José, British Honduras; Washington.

1940 Late Ceramic Horizons at Benque Viejo, British Honduras; Contr. to American Anthr. and History No. 35; Washington.

1959 The Role of Caves in Maya Culture; In: Amerikanistische Miszellen, pp. 122-29; Hamburg.

1965 Archaeological Synthesis of the Southern Maya Lowlands;

In: Handbook of Middle American Indians, Vol. 2, pp. 33159; Austin.

G. R. WIILEy et al.

1965 Prehistoric Maya Settlements in the Belize River Valley;

Papers Peabody Museum LIV; Cambridge. 


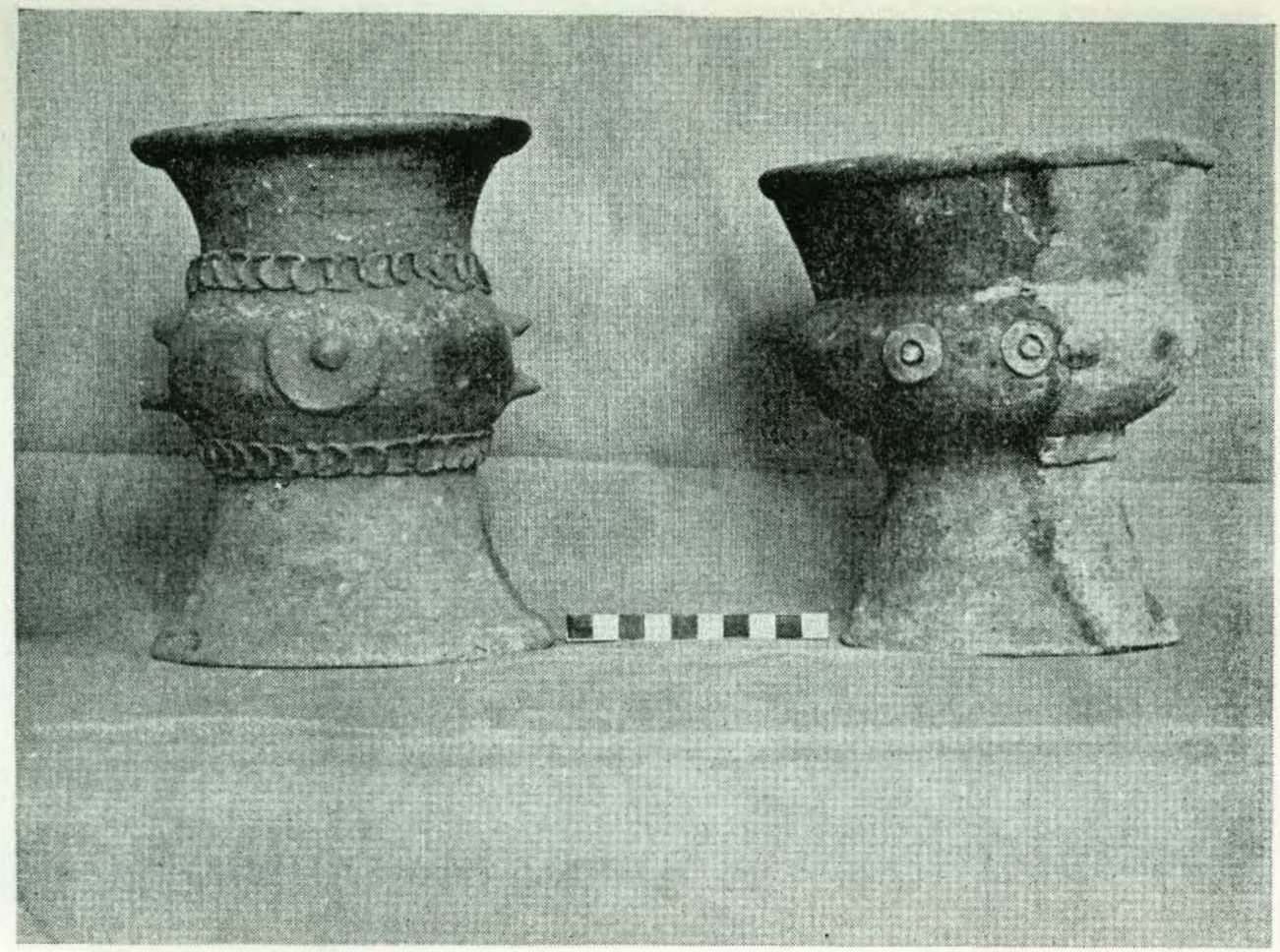

a

b

FIG. 2

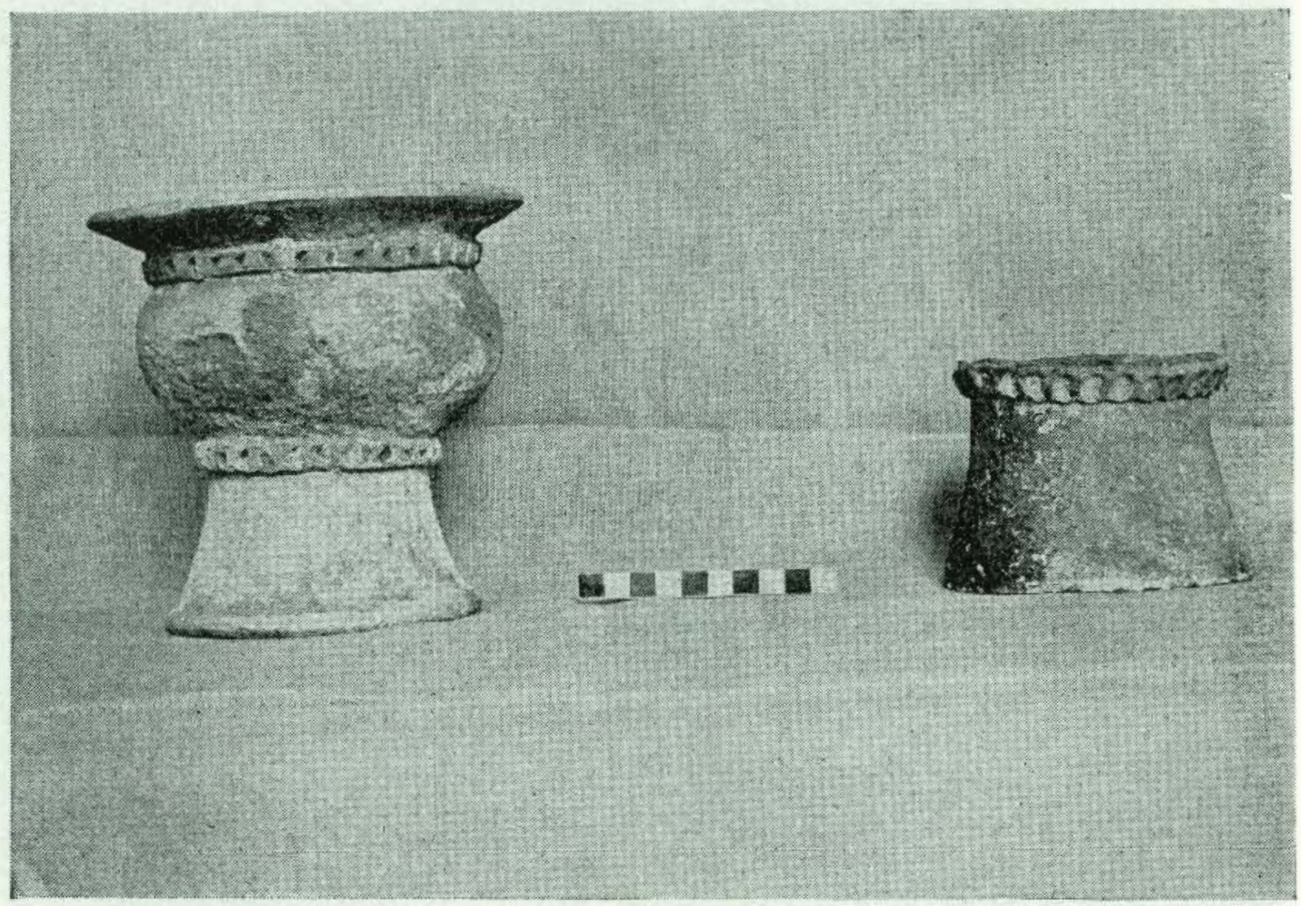

a

b

FIG. 3

Estudios de Cultura Maya. Vol. X, 1976/7

Instituto de Investigaciones Filológicas/ Facultad de Filosofía y Letras

Centro de Estudios Mayas, UNAM

http://www.iifilologicas.unam.mx/estculmaya/ 


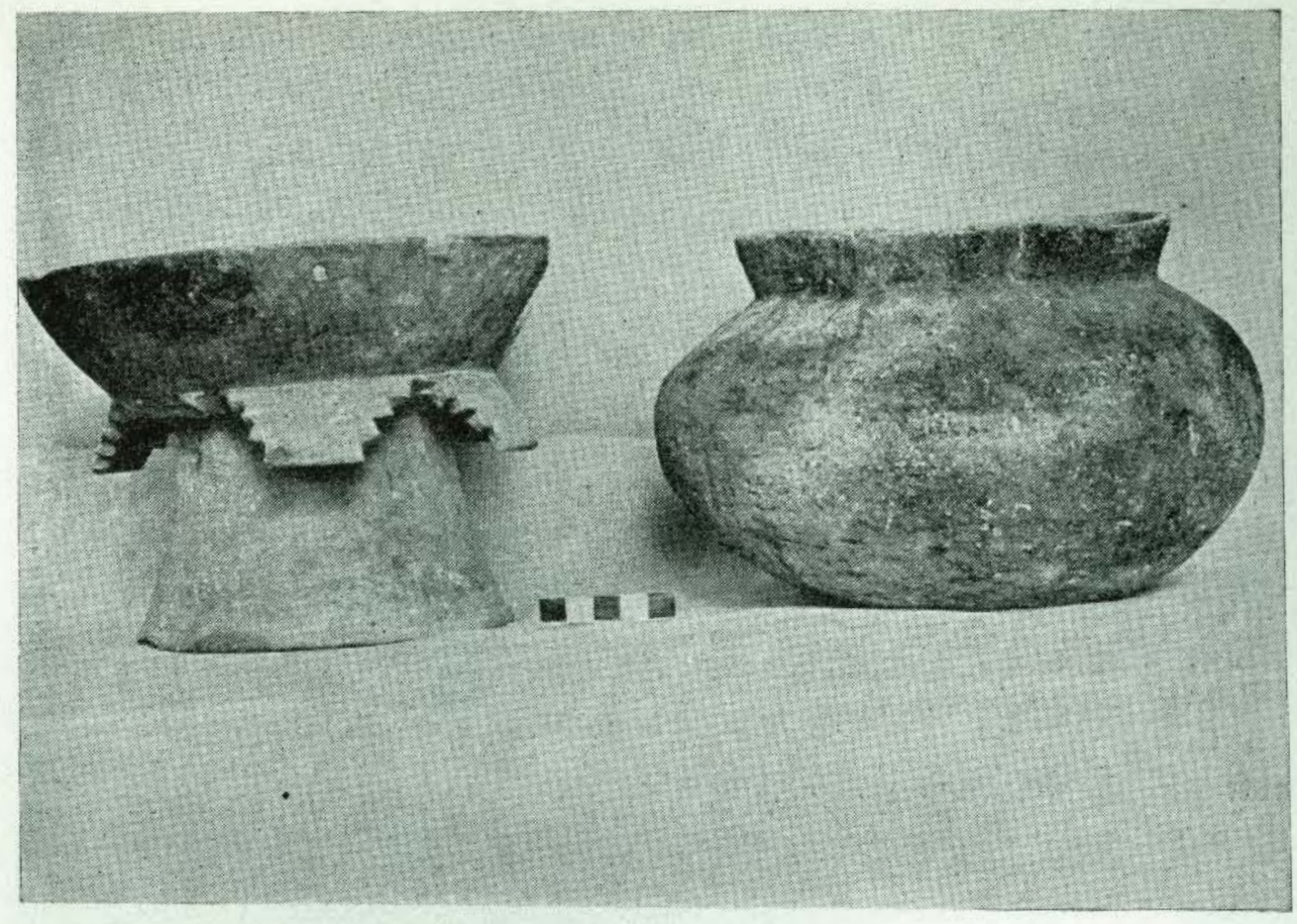

a

FIG. 4

b

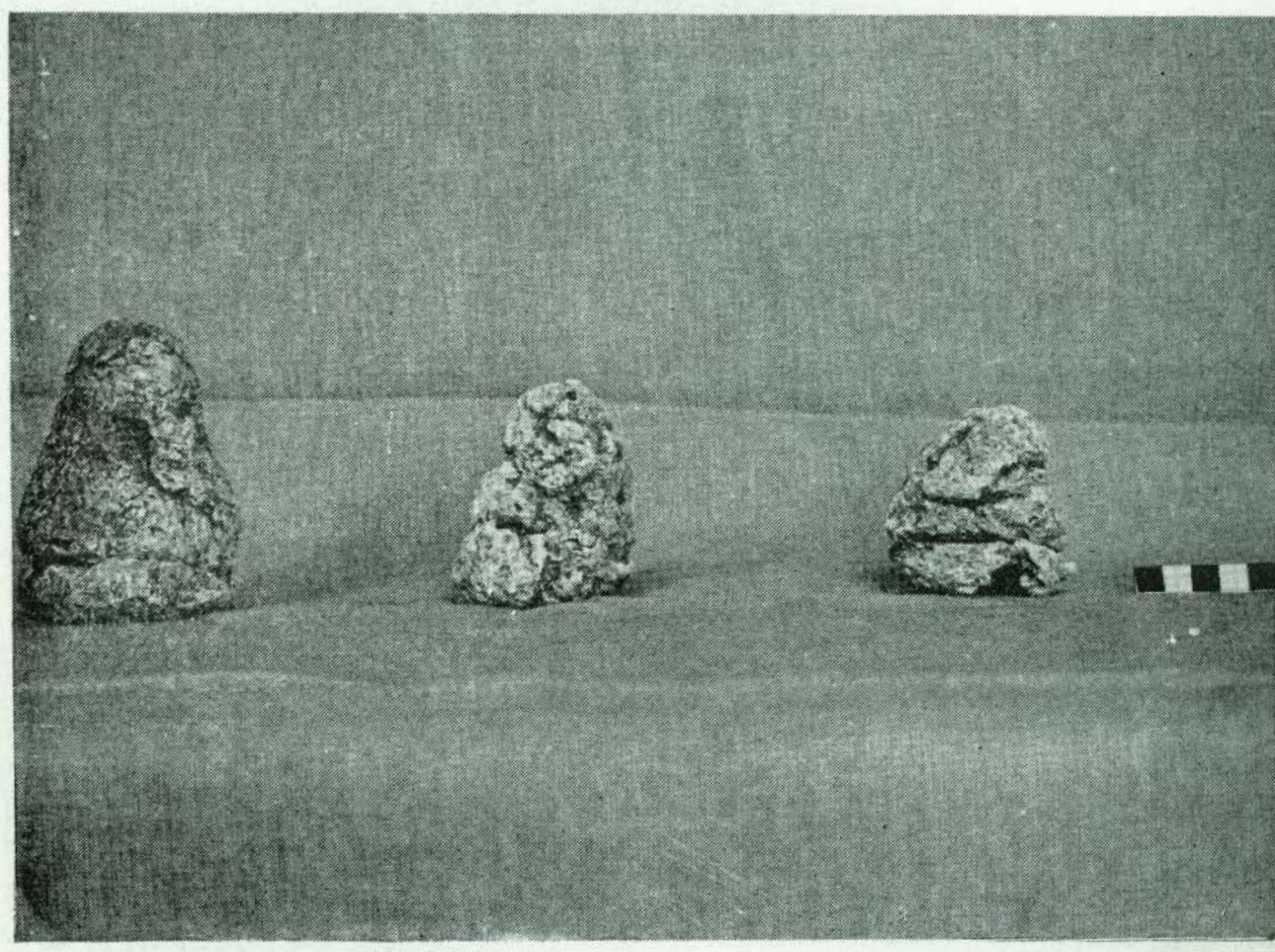

a

b

FIG. 5

Estudios de Cultura Maya. Vol. X, 1976/7

Instituto de Investigaciones Filológicas/ Facultad de Filosofía y Letras

Centro de Estudios Mayas, UNAM

http://www.iifilologicas.unam.mx/estculmaya/ 


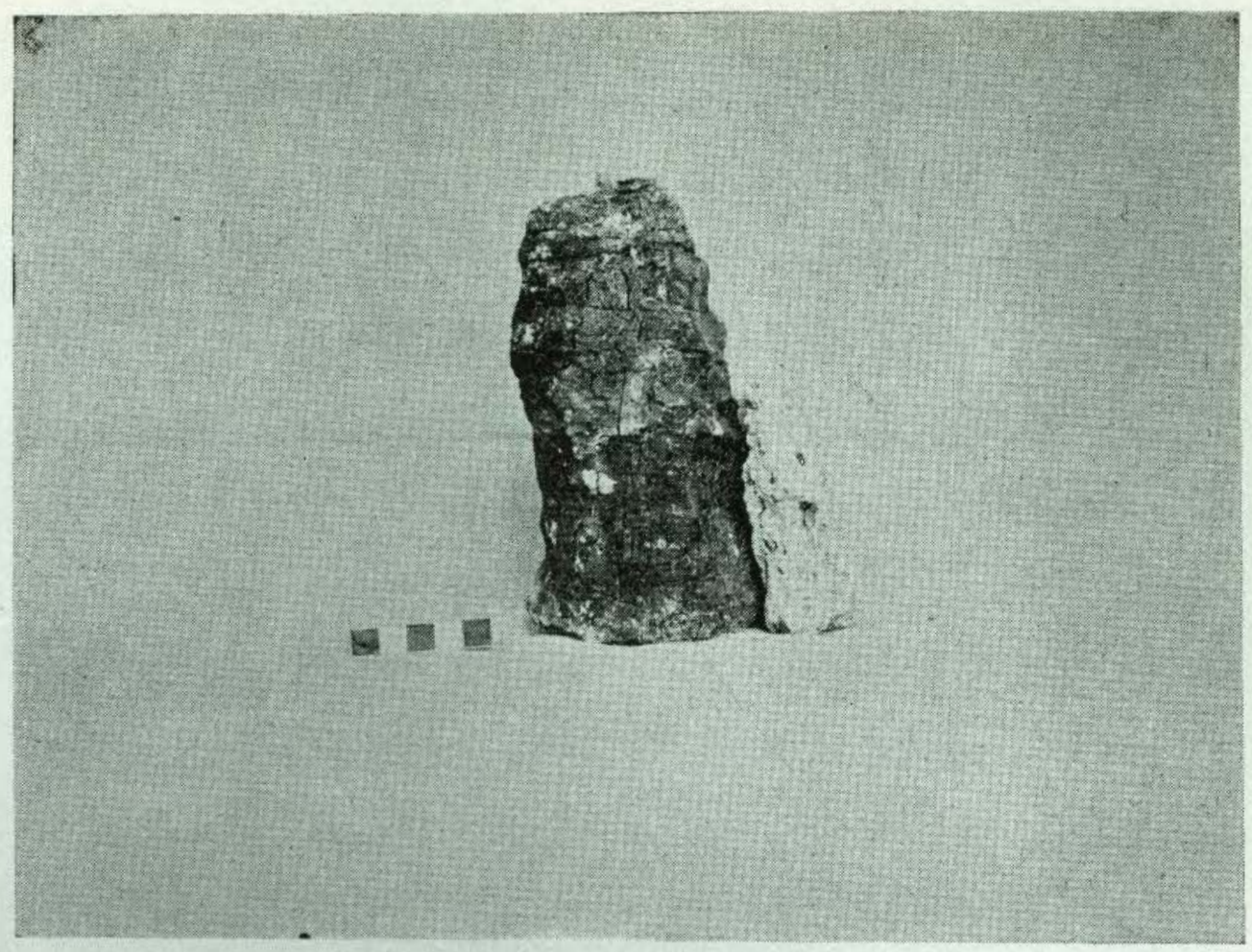

Fig. 6

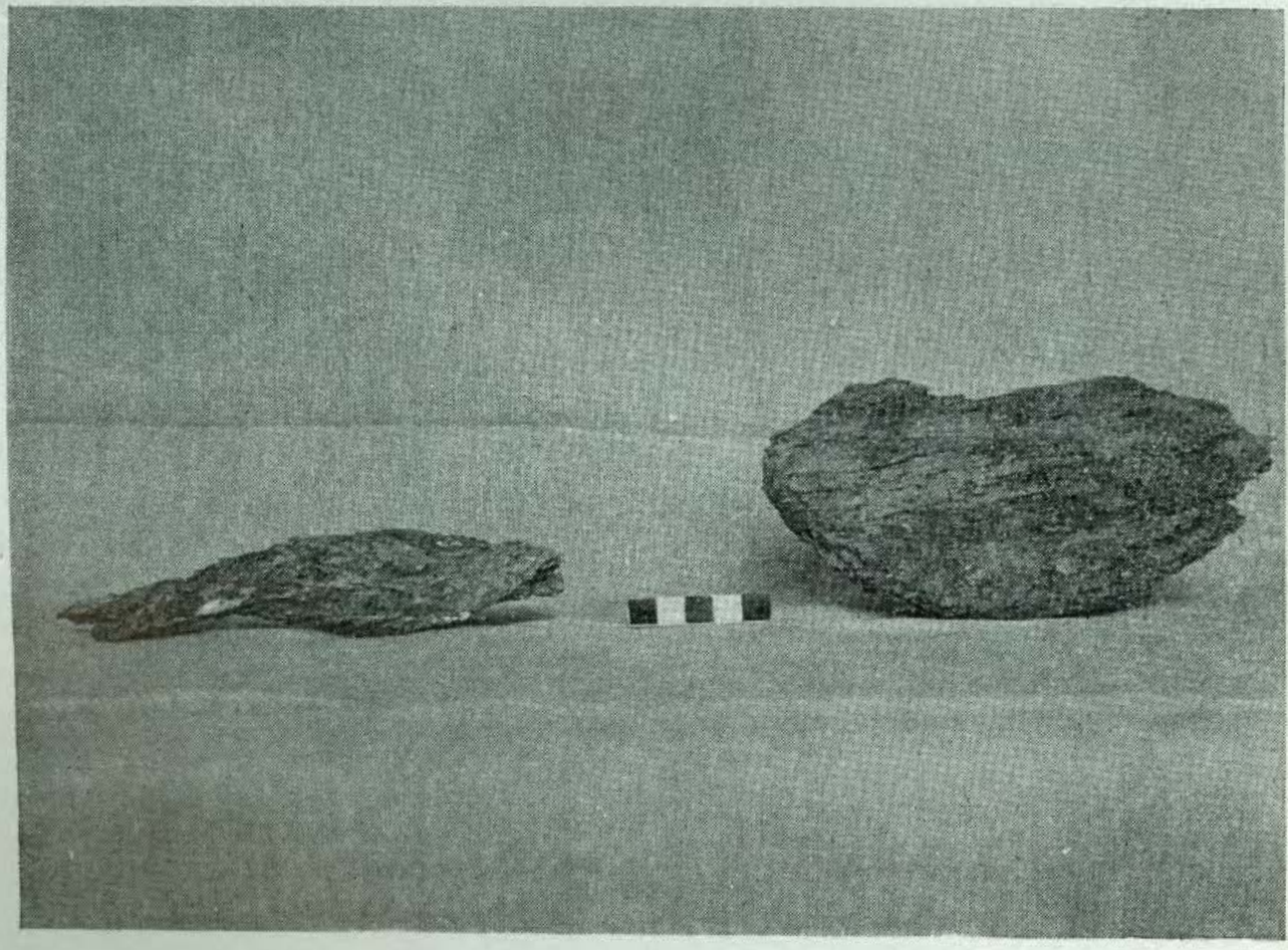

a

b

Fig. 7

Estudios de Cultura Maya. Vol. X, 1976/7

Instituto de Investigaciones Filológicas/ Facultad de Filosofía y Letras Centro de Estudios Mayas, UNAM

http://www.iifilologicas.unam.mx/estculmaya/ 


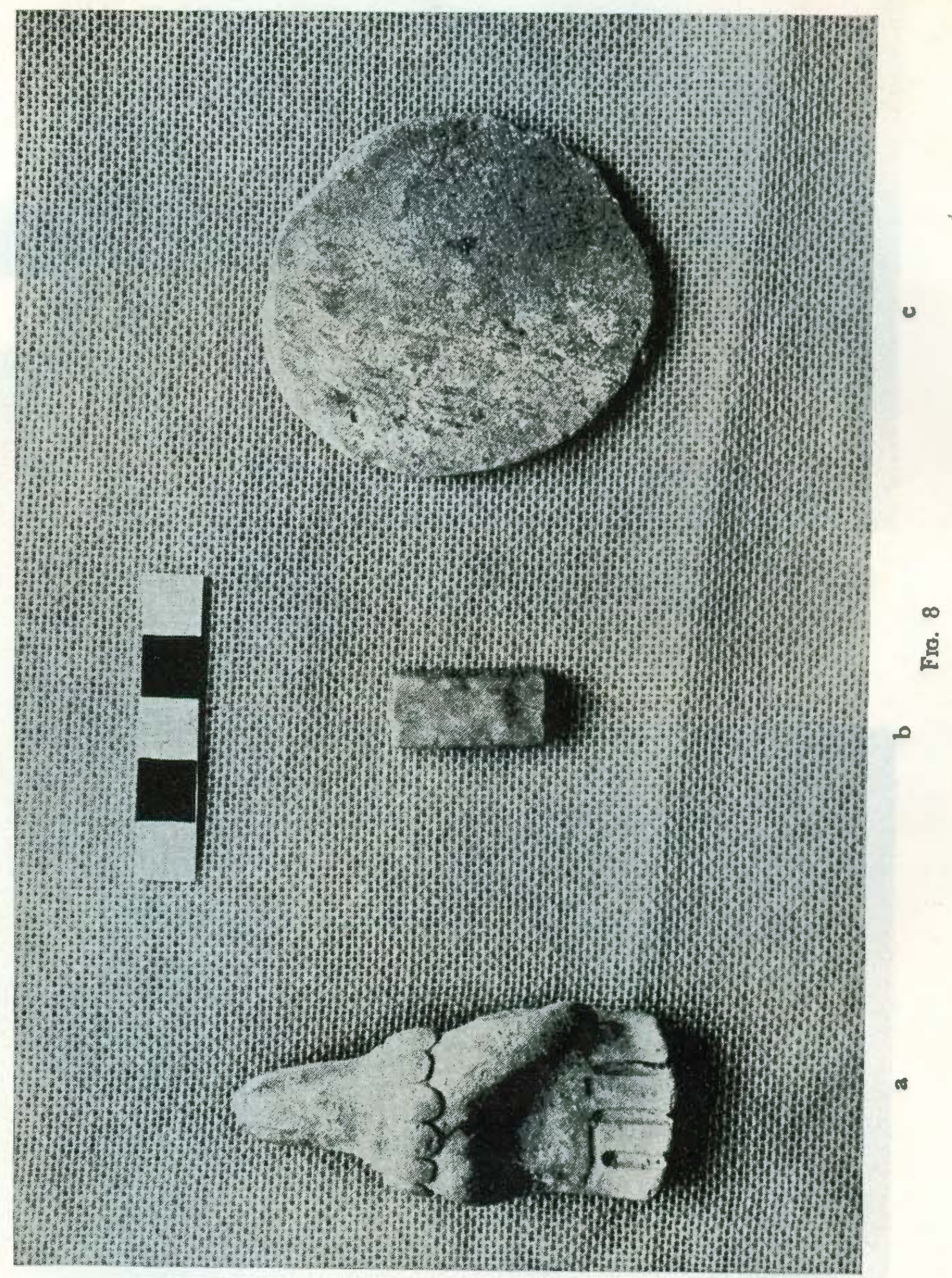

Estudios de Cultura Maya. Vol. X, 1976/7

Instituto de Investigaciones Filológicas/ Facultad de Filosofía y Letras

Centro de Estudios Mayas, UNAM

http://www.iifilologicas.unam.mx/estculmaya/ 